〈原 著〉

\title{
環境清拭用クロスの微生物に対する性能評価
}

\author{
中村 $\quad$ 絵美1,3) $\cdot$ 高見 $\quad$ 貴之 ${ }^{1)} \cdot$ 加藤 頼子 ${ }^{1)} \cdot$ 吉田 葉子 2,3$) \cdot$ 谷口 暢 ${ }^{1)}$
}

\section{Evaluation of Sanitizing and Inactivation Efficacy of Wet Wipes against Bacteria and Viruses}

\author{
Emi NakAmura ${ }^{1,3)}$, Takashi TAKAmi ${ }^{1)}$, Yoriko KATO $^{1)}$, Yoko YoshidA ${ }^{2,3)}$ and Toru TAniguchi ${ }^{1)}$ \\ ${ }^{1)}$ Biochemical Laboratory, ${ }^{2)}$ Academic Division, Saraya Co., Ltd., \\ 3) Faculty of Healthcare, Tokyo Healthcare University Postgraduate School
}

$(2015$ 年 6 月 22 日 受付 $\cdot 2015$ 年 12 月 21 日 受理)

\begin{abstract}
要旨
医療施設に抢ける環境由来による微生物の感染予防には, 手指衛生に加えて環境表面の清掃が非 常に重要であり, 時として消毒も必要となる. 近年, 病院環境の整備に, 洗浄剤や消毒薬(薬液)を 不織布等のクロスに含浸させた環境清拭用クロスが頻用されている.しかし, 環境清拭用クロスに は，薬液中の成分がクロスに吸着し成分濃度が低下する場合があるにもかかわらず，その殺菌性能 の評価の多くは，クロスに含浸させようとする薬液を微生物に作用させる方法が実施されている. そこで, 3 種類の市販品(市販品 A, B と C) と消毒用エタノールクロスについて(1)クロスからの絞 り液と供試微生物を作用させるクロス含浸後定量的懸濁法と (2) 環境清拭用クロスを直接利用した 清拭法によって殺菌効果抢よびウイルス不活化効果を検討した. その結果, 市販品 A は, 市販品 $\mathrm{B}$ 抢よび C と比較してクロス含浸後定量的懸濁法と清拭法ともに高い殺菌効果抢よびウイルス不 活化効果を示した。ささらに市販品 $\mathrm{A}$ は, 消毒用エタノールクロスと比較しても, 清拭法において 高いウイルス不活化効果を示した. また, 市販品 B, C 抢よび消毒用エタノールクロスでは, クロ ス含浸後定量的懸濁法と清拭法で結果に明確な差が認められた。 そのため, 環境清拭用クロスの有 効性評価には, クロス含浸後定量的懸濁法による評価に加えて, 実際の環境整備を想定した清拭法 も評価法として重要と考えられた.
\end{abstract}

Key words : 環境整備, 環境清拭用クロス, 絞り液, 懸濁法, 清拭法

\section{はじめに}

近年，医療施設において，薬剤耐性菌やウイルスなど の病原微生物に污染された環境を介した医療関連感染が 発生し，感染予防に対する意識が高まっている1,2)。医 療施設における環境由来による微生物の感染予防には, 手指衛生に加えて, 環境表面の清掃が重要であり，時と して消毒の必要性が指摘されている2,3). それに伴い, 環境整備を効率よく実施する方法のひとつとして, 洗浄 剂や消毒薬(薬液)を不織布等のクロスに含浸させた薬液 含浸ウエットクロス(以下, 環境清拭用クロス)の需要が 増加し, 様々な特徵を有した数多くの製品が販売されて

サラヤ株式会社 1) バイオケミカル研究所, 2) 学術部, 3) 東京医 療保健大学大学院医療保健学研究科
いる.しかし, それらの殺菌性能の評価の多くは, クロ スに含浸させようとする薬液を微生物に作用させる方法 によるものが多い。しかしながら，環境清拭用クロス は, 薬液中の成分がクロスに吸着し, 成分濃度が低下す る場合があることから，クロスに含浸させようとする薬 液を供試微生物に作用させる方法では, 環境清拭用クロ スの評価としては不十分と考えられる ${ }^{4 \sim 7)}$.

そこで，本研究では， 3 種類の市販品および消毒用工 タノールクロスについて, 薬液中の成分がクロスに吸着 することを考慮し, クロスからの絞り液と供試微生物を 作用させる方法 (以下，クロス含浸後定量的懸濁法)によ って, 殺菌効果およびウイルス不活化効果を検討した. さらに，実際の環境整備を想定し，一般社団法人日本衛 生材料工業連合会から提案されている「ウエットワイ 
パー類の除菌性能試験方法」の「拭取り装置」を用いた 試験法である清拭法に準じて, 殺菌効果およびウイルス 不活化効果も検討した ${ }^{8)}$.

\section{材料と方法}

\section{1. 環境清拭用クロス}

第四級アンモニウム塩が配合された市販環境清拭用ク ロス 3 種(市販品 $\mathrm{A}$ の成分 : 第四級アンモニウム塩, エ タノール, アルカリ剂, $\mathrm{pH}$ 調整剂, 材質: レーヨン, ポリエステル, 複合繊維, サラヤ株式会社; 市販品 B の成分：第四級アンモニウム塩, アルカリ剂, 水, 基 材：レーヨン不織布，ハクゾウメディカル株式会社 ; 市 販品 Cの成分：ジデシルジメチルアンモニウムクロラ イド, アルキルグルコシド, アルキルアミンオキシド, ペーパー材質：レーヨン, ポリエチレンテレフタレー ト, ポリエチレン, ポリプロピレン, 花王プロフェッシ ヨナル・サービス株式会社)を使用した(全てメーカー公 表). また, 市販品 $\mathrm{A}$ に使用されているクロスに, 市販 品 $\mathrm{A}$ と同量の $81 \mathrm{vol} \%$ エタノールを含ませたもの(以 下, 消毒用エタノールクロス) も作製し, 使用した。

\section{2. クロス含浸後定量的懸濁法}

\section{1）細菌および真菌に対する評価方法}

環境清拭用クロス扮よび消毒用エタノールクロス絞り 液の細菌抢よび真菌に対する有効性評価には, 米国食品 医薬品局が定めた暫定的最終評価基準 (Food and Drug Administration's Tentative Final Monograph: FDATFM) において, 医療関連感染症の代表菌株として指 定されているPseudomonas aeruginosa ATCC 15442, Serratia marcescens ATCC 14756, Staphylococcus aureus ATCC 6538, Staphylococcus epidermidis ATCC 12228, Candida albicans ATCC 10231, その他医療関連感染 症原因菌である Acinetobacter baumannii JCM 6841, Burkholderia cepacia JCM 5964, Escherichia coli ATCC 11229 および薬剤耐性菌であるP. aeruginosa GTC 2017, Enterococcus faecalis ATCC 51299, S. aureus ATCC 700698 を使用した.

本試験は, 米国試験材料協会 (American Society for Testing and Materials: ASTM)が定めるASTM E 2315-03 に準じて行った ${ }^{9)}$. 各株を最適条件で培養し, 供試菌液を調製した．細菌は，普通ブイヨン培地を用い て $37^{\circ} \mathrm{C} ， 24$ 時間振とう培養(ただし，S. epidermidis は $37^{\circ} \mathrm{C}, 48$ 時間振とう培養)し，その培養液を用いた。真 菌は, ポテトデキストロース寒天培地で $30^{\circ} \mathrm{C}, 48$ 時間 培養後, 生理食塩水を用いて回収し, 遠心分離後, 生理 食塩水で再懸濁した回収液を用いた。環境清拭用クロス および消毒用エタノールクロスからの絞り液は, 万力を 用いて得, 各絞り液 $9.5 \mathrm{~mL}$ に供試菌液 $0.5 \mathrm{~mL}$ を加え, $20^{\circ} \mathrm{C}$ に保持しながら 10 秒間作用させた. 作用後, 0.5
$\mathrm{mL}$ を採取し, 不活性化剂(薬液に対して不活化効果を 示し, かつ, 菌の発育を阻害しない条件から，10\%ポ リソルベート 80 と $3 \%$ 大豆レシチンの混合溶液を使用) $4.5 \mathrm{~mL}$ に加え, 十分に混合して薬液の作用を停止した 後, 生理食塩水で 10 倍希釈法による希釈系列を作製し た。細菌の場合は，希釈液 $1.0 \mathrm{~mL}$ を約 $50^{\circ} \mathrm{C}$ の普通寒 天培地と混合, 真菌の場合は, 希釈液 $0.1 \mathrm{~mL}$ をポテト デキストロース寒天培地に塗沫し, 各株を最適条件で培 養した. 培養後, コロニー数 $(\mathrm{CFU} / \mathrm{mL})$ を計測し, 有 効性を評価した。

\section{2） ウイルスに対する評価方法}

環境清拭用クロス抢よび消毒用エタノールクロス絞り 液のウイルスに対する有効性評価には，エンベロープウ イルスの Influenza A virus (H1N1) ATCC VR-1469(宿 主細胞 : Madin-Darby canine kidney cell) およびノンエ ンベロープウイルスの Feline calicivirus ATCC VR-782 (宿主細胞 : Crandell-Reese feline kidney cell), Murine norovirus S7 (宿主細胞 : Mouse monocyte/macrophage cell line RAW264), Adenovirus Type5/Adnoid75 ATCC VR-5(宿主細胞 : HeLa cell)を使用した.

本試験は，ドイツウイルス疾病管理協会 (Deutsche Vereinigung zur Bekä mpfung der Viruskrankheiten: DVV) 抢よびロベルト・コッホ研究所 (Robert Koch Institute: RKI)による医療に抢けるウイルスに対する化学 消毒剂の試験に関するガイドライン（以下，DVV\&RKI ガイドライン)の “タンパク質を負荷しない条件”に準 じて行った ${ }^{10,11)}$. 環境清拭用クロスまたは消毒用エタ ノールクロスの絞り液, 滅菌精製水, ウイルス培養液を 8: 1:1の割合で混合して, $20^{\circ} \mathrm{C}$ に保持しながら 1 分 間作用させた。作用後, $0.1 \mathrm{~mL}$ を採取し, 不活性化剂 (10\%血清と細胞培養用培地の混合溶液を使用) $0.9 \mathrm{~mL}$ に加え，十分に混合して薬液の作用を停止した．その 後, 細胞培養用培地で 10 倍希釈法による希釈系列を作 製した後，それぞれのウイルスに対応する宿主細胞に接 種した。一定時間後にウイルス感染の有無を観察し， $\mathrm{TCID}_{50}$ 法 (Behrens-Kärber 法)によってウイルス感染価 を算出し, 有効性を評価した ${ }^{12}$.

\section{3. 清拭法 \\ 1）試験装置}

本試験では，環境清拭用クロスによる清拭を模擬的に 行うため, 日本衛生材料工業連合会の「ウエットワイ パー類の除菌性能試験方法」に準拠して作製した拭取り 装置を用いた8,13) (図 1)。これはモデル污れを塗布した 試験担体 (ステンレス板 : $25 \mathrm{~mm} \times 150 \mathrm{~mm}$ )を設置した レール上を，環境清拭用クロスを巻きつけたおもり[拭 取り面 $(24 \mathrm{~mm} \times 14 \mathrm{~mm})$ に $150 \mathrm{~g}$ の荷重がかかるように 設計]で，作業者による負荷をかけずに清拭する装置で ある。 


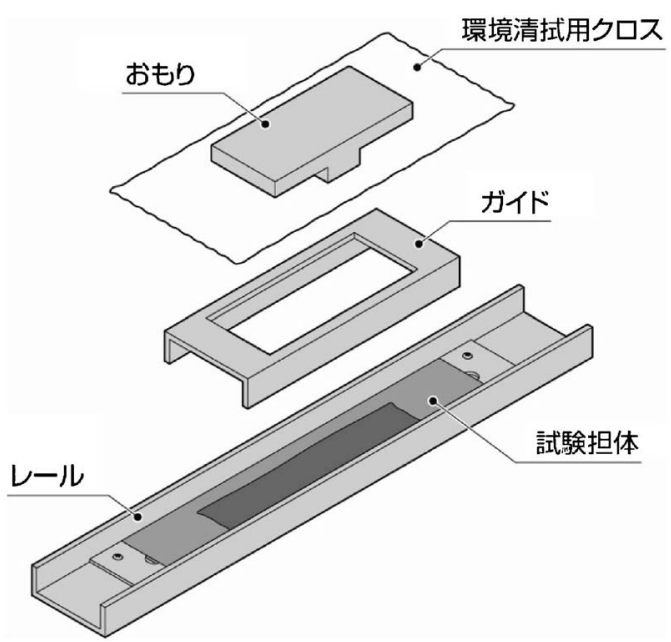

図 1 拭取り装置

\section{2）細菌に対する評価方法}

環境清拭用クロス抢よび消毒用エタノールクロスによ る清拭での細菌に対する有效性評価には, A. baumannii JCM 6841, P. aeruginosa GTC 2017, E. faecalis ATCC 51299 および S. aureus ATCC 700698 を使用した.

本試験は, 日本衛生材料工業連合会の「ウエットワイ パー類の除菌性能試験方法」を参考にして行った. 供試 菌液[培養菌液と $6 \mathrm{~g} / \mathrm{L}$ ウシ血清アルブミン $(\mathrm{BSA})$ 水溶 液を等量ずつ混合したもの] $10 \mu \mathrm{L}$ を試験担体中央部 $(15 \mathrm{~mm} \times 90 \mathrm{~mm})$ に白金耳を用いて叙り広げ， 5 分間乾 燥させて污染試験担体を作製し, レール上に設置した。 次に, ガイドをレールに設置し, 環境清拭用クロスを装 着(クロスを 2 つ折りにして, 伸びの大きい方向と拭取 り方向が同じになるように装着)したおもりを，ガイド 上面の開口部に設置した。扮もりを上から軽く抒さえ, 環境清拭用クロス抢よび消毒用エタノールクロスが污染 試験担体に密着するように調整した後, ガイド部分の横 を持ち，上から圧をかけないように，レールに沿って污 染試験担体表面上を清拭した $[1$ 往復(清拭距離 : 一方向 につき $140 \mathrm{~mm}$ )を約 2 秒で清拭し, これを 5 往復行っ た]. 清拭後の試験担体は, 打もりをレール上から外し た後, 2 分間放置した. 放置後, 滅菌済みピンセットで 取り外し, 不活性化剂(10\%ポリソルベート 80 と $3 \%$ 大 豆レシチンの混合溶液を使用) $20 \mathrm{~mL}$ が入ったストマッ カ一袋に入れ, 外側から試験担体表面を 1 分間よく擦 り,もみだし操作を行った。.その後 5 分間放置し, 再 度 1 分間もみだし操作を行った後, 不活性化剂を回収 した. 回収した不活性化剂は, 生理食塩水で 10 倍希釈 法による希釈系列を作製した後, 各希釈液 $1.0 \mathrm{~mL}$ を約 $50^{\circ} \mathrm{C}$ の普通ブイヨン寒天培地と混合し， $37^{\circ} \mathrm{C} て ゙ ~ 1$ 日間 培養した. 培養後, コロニー数 $(\mathrm{CFU} / \mathrm{mL})$ を計測し, 有效性を評価した。試験は室温 $\left(25^{\circ} \mathrm{C}\right)$ で 3 回実施し,
平均值を算出した。な扔, 乾燥直後の污染試験担体から 回収したものを未処理, 市販品 $\mathrm{A}$ に使用されているク ロスを隇菌し, 市販品 $\mathrm{A}$ と同量の隇菌精製水を含ませ たものを用いて清拭したものを水拭きとした.

\section{3） ウイルスに対する評価方法}

環境清拭用クロス抢よび消毒用エタノールクロスによ る清拭でのウイルスに対する有效性評価には, Influenza A virus (H1N1) ATCC VR-1469 および Feline calicivirus ATCC VR-782 使用した.

本試験は, 日本衛生材料工業連合会の「ウエットワイ パー類の除菌性能試験方法」を参考にして行った。供試 ウイルス液「ウイルス液(ウイルス培湌液を $\operatorname{PBS}(-)$ に 置換した後, LB 培地で希釈したもの) と $6 \mathrm{~g} / \mathrm{L} \mathrm{BSA}$ 水 溶液を等量ずつ混合したもの] $100 \mu \mathrm{L}$ を, 試験担体中 央部 $(15 \mathrm{~mm} \times 90 \mathrm{~mm})$ に白金耳を用いて塗り広げ，15 分間乾燥させて污染試験担体を作製し，レール上に設置 した. 次に, 污染試験担体を，3-2) と同様の方法で清 拭した。清拭後の試験担体は, 不活性化剂(10\%血清々 細胞培養用培地の混合溶液) $20 \mathrm{~mL}$ が入ったストマッ カー袋に入れ， 1 分間も及だし操作を行った．その後 5 分間静置し, 再度 1 分間もみだし操作を行い, 不活性 化剂を回収した。回収した不活性化剂は, 細胞培養用培 地で 10 倍希釈法による希釈系列を作製した後, 宿主細 胞に接種した。一定時間後にウイルス感染の有無を観察 し， TCID 50 法 (Behrens-Kärber 法)によってウイルス感 染価を算出し, 有効性を評価した。試験は室温 $\left(25^{\circ} \mathrm{C}\right)$ で 3 回実施し, 平均值を算出した.

\section{結果}

\section{1. クロス含浸後定量的懸濁法}

1）細菌および真菌に対する効果

環境清拭用クロス抢よび消毒用エタノールクロス絞り 液の細菌抢よび真菌に対する殺菌効果を表 1 に示した. 市販品 $\mathrm{A}$ 打よび消毒用エタノールクロスの絞り液は, 10 秒間の作用後, 試験した全株に抢いて菌が検出され ず，高い殺菌効果を示した。一方，市販品 $\mathrm{B}$ 抢よび市 販品 C に抢いては, 10 秒間の作用後, 一部の菌株 $(B$. cepacia JCM 5964, E. coli ATCC 11229, P. aeruginosa ATCC 15442, P. aeruginosa GTC 2017, S. marcescens ATCC 14756 およびC. albicans ATCC 10231) において 菌が検出された。

\section{2）ウイルスに対する効果}

環境清拭用クロス抢よび消毒用エタノールクロス絞り 液のウイルスに対する不活化効果を表 2 に示した．市販 品 $\mathrm{A}$ の絞り液は, 試験した全てのウイルスの $\mathrm{TCID}_{50}$ を $4 \log _{10}$ 以上減少させ, DVV\&RKI ガイドラインの評 価基準を満たすウイルス不活化効果を示した。一方，市 販品 $\mathrm{B}$, 市販品 $\mathrm{C}$ 抢よび消毒用エタノールクロスにお 
表 1 環境清拭用クロスおよび消毒用エタノールクロス絞り液の細菌および真菌に対する殺菌効果

\begin{tabular}{|c|c|c|c|c|c|}
\hline & \multirow{2}{*}{ 菌 } & \multicolumn{4}{|c|}{ 菌数減少率(\%) } \\
\hline & & 市販品 A & 市販品 B & 市販品 C & 消毒用エタノールクロス \\
\hline \multirow{6}{*}{$\begin{array}{c}\text { 細菌 } \\
\text { （グラム陰性菌） }\end{array}$} & A. baumannii JCM 6841 & $>99.999$ & $>99.999$ & $>99.999$ & $>99.999$ \\
\hline & B. cepacia JCM 5964 & $>99.999$ & 2.857 & 34.286 & $>99.999$ \\
\hline & E. coli ATCC 11229 & $>99.999$ & 69.643 & $>99.999$ & $>99.999$ \\
\hline & P. aeruginosa ATCC 15442 & $>99.999$ & 91.500 & 98.900 & $>99.999$ \\
\hline & P. aeruginosa GTC 2017 & $>99.999$ & 87.857 & 96.857 & $>99.999$ \\
\hline & S. marcescens ATCC 14756 & $>99.999$ & 83.077 & 99.998 & $>99.999$ \\
\hline \multirow{4}{*}{$\begin{array}{c}\text { 細菌 } \\
\text { (グラム陽性菌) }\end{array}$} & E. faecalis ATCC 51299 & $>99.999$ & 99.999 & $>99.999$ & $>99.999$ \\
\hline & S. aureus ATCC 6538 & $>99.999$ & 99.999 & 99.999 & $>99.999$ \\
\hline & S. aureus ATCC 700698 & $>99.999$ & $>99.999$ & $>99.999$ & $>99.999$ \\
\hline & S. epidermidis ATCC 12228 & $>99.999$ & $>99.999$ & $>99.999$ & $>99.999$ \\
\hline 真菌 & C. albicans ATCC 10231 & $>99.999$ & 76.364 & 99.984 & $>99.999$ \\
\hline
\end{tabular}

表 2 環境清拭用クロスおよび消毒用エタノールクロス絞り液のウイルスに対する不活化効果

\begin{tabular}{|c|c|c|c|c|c|}
\hline & \multirow{2}{*}{ ウイルス } & \multicolumn{4}{|c|}{ 対数減少値 $\left(-\log _{10} T C I D_{50}\right)$} \\
\hline & & 市販品 A & 市販品 B & 市販品 C & 消毒用エタノールクロス \\
\hline エンベロープウイルス & Influenza A virus ( $\mathrm{H} 1 \mathrm{~N}$ 1) ATCC VR-1469 & $>4.25$ & 4.00 & $>4.25$ & $>4.50$ \\
\hline \multirow{3}{*}{ ノンエンベロープウイルス } & Feline calicivirus ATCC VR-782 & $>4.00$ & 0.25 & 0.25 & 0.25 \\
\hline & Murine norovirus S 7 & $>4.00$ & 0.50 & 0.75 & N.D. \\
\hline & Adenovirus Type 5/Adnoid 75 ATCC VR-5 & $>4.25$ & 0.25 & 2.25 & N.D. \\
\hline
\end{tabular}

N.D. : 未実施
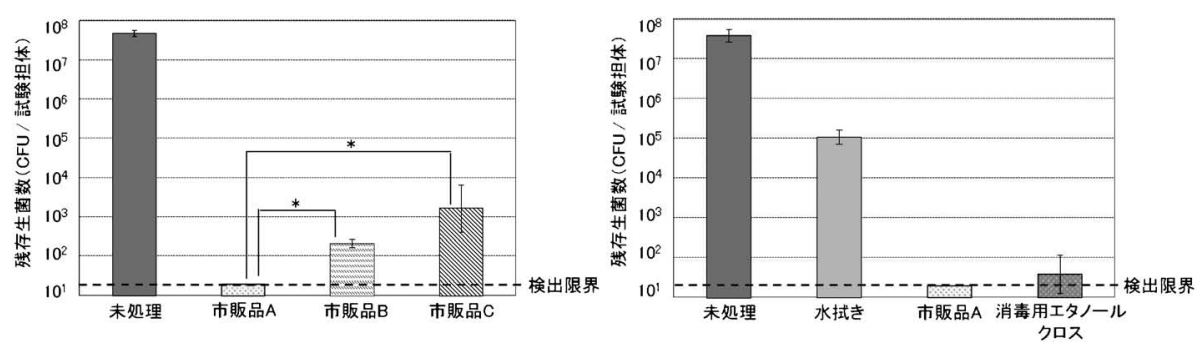

図 2 A. baumannii JCM 6841 に対する拭取り殺菌効果 $(m e a n \pm$ S.D., $\mathrm{n}=3)$

$$
*: \mathrm{p}<0.05
$$

いては，DVV\&RKI ガイドラインの評価基準を満たす ウイルス不活化効果を示したものは, Influenza A virus (H1N1) ATCC VR-1469 のみであった.

\section{2. 清拭法}

1）細菌に対する効果

環境清拭用クロスおよび消毒用エタノールクロスによ る清拭での細菌に対する殺菌効果を図 2〜5に示した. 市販品 $\mathrm{A}$ を用いた清拭では, 試験した全株において試 験担体から菌が検出されず，市販品 B および市販品 C と比較して, 高い殺菌効果を示した $\left(^{*}: \mathrm{p}<0.05,{ }^{* *}\right.$ : $0.05<\mathrm{p}<0.1)$.また，消毒用エタノールクロスでは， 一部の菌株 ( A. baumannii JCM 6841 抢よび $P$. aeruginosa GTC 2017)において菌が検出された.

\section{2） ウイルスに対する効果}

環境清拭用クロスおよび消毒用エタノールクロスによ る清拭でのウイルスに対する不活化効果を図 6 と図 7 に 示した。市販品 $\mathrm{A}$ を用いた清拭では, 試験担体からウ イルスがほぼ検出されず，市販品 $\mathrm{B}$ ，市販品 $\mathrm{C}$ 打よび 消毒用エタノールクロスと比較して，高いウイルス不活 化効果を示した $\left(^{*}: \mathrm{p}<0.05,{ }^{* *}: 0.05<\mathrm{p}<0.1\right)$.

\section{考察}

クロス含浸後定量的懸濁法では，市販品 A について は, 試験に用いた全ての微生物 (医療関連感染症原因菌 11 菌種抢よび医療関連感染等の原因となるウイルス 4 種)に対して，効果的な殺菌効果抢よびウイルス不活化 

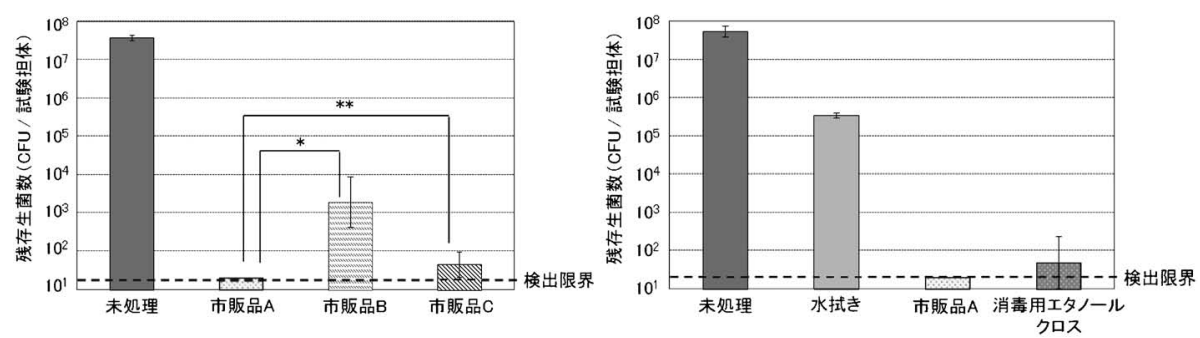

図 3 P. aeruginosa GTC 2017 に対する拭取り殺菌効果 $(m e a n \pm$ S.D., $n=3)$ $*: \mathrm{p}<0.05,{ }^{* *}: 0.05<\mathrm{p}<0.1$
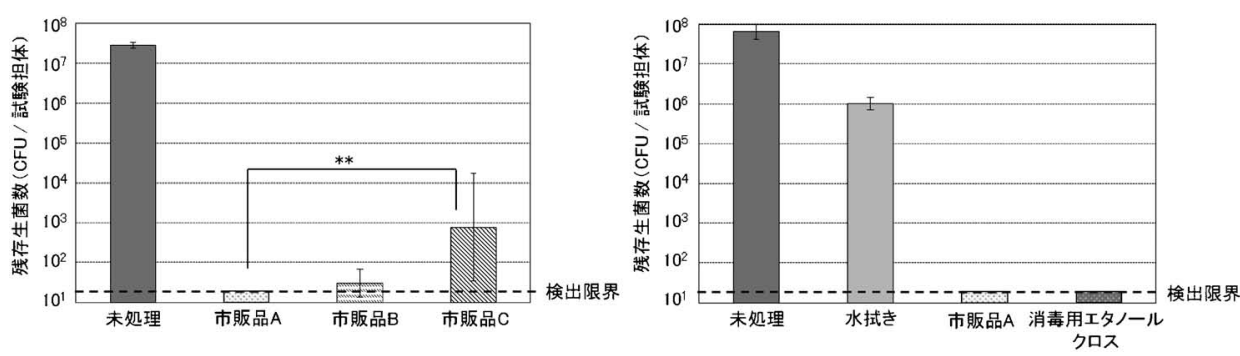

図 4 E. faecalis ATCC 51299 に対する拭取り殺菌効果 (mean \pm S.D., $\mathrm{n}=3$ ) $* *: 0.05<\mathrm{p}<0.1$
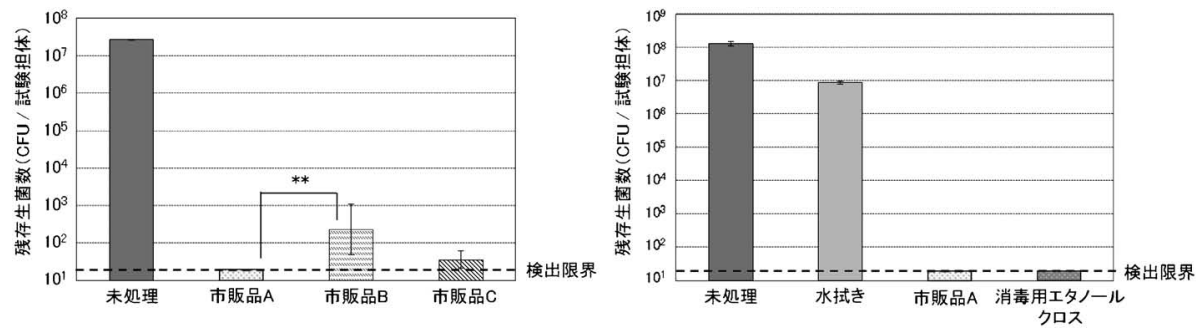

図 5 S. aureus ATCC 700698 に対する拭取り殺菌効果 $($ mean \pm S.D., $n=3)$ $* *: 0.05<\mathrm{p}<0.1$
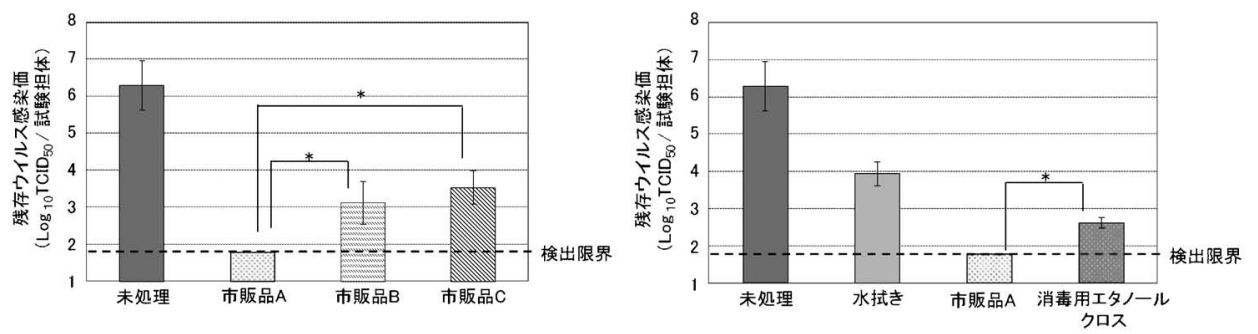

図 6 Influenza A virus (H1N1) ATCC VR-1469 に対する拭取り不活化効果 (mean \pm S.D., n=3) $*: p<0.05$
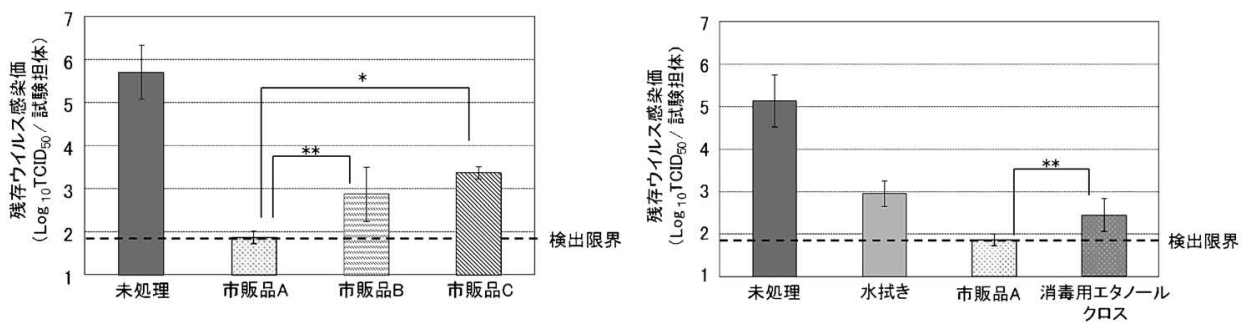

図 7 Feline calicivirus ATCC VR-782 に対する拭取り不活化効果 (mean \pm S.D., $n=3)$ $*: \mathrm{p}<0.05$, $^{* *}: 0.05<\mathrm{p}<0.1$ 
効果を示した。一方, 市販品 $\mathrm{B}$ と市販品 Cでは, 殺菌 効果抢よびウイルス不活化効果を示さなかった微生物が 認められた。消毒用エタノールクロスの絞り液において も, 高い殺菌効果が認められたことから, 市販品 $\mathrm{A} の$ 効果は, エタノールに起因することが推察される. 塩化 ベンザルコニウムやジデシルジメチルアンモニウムクロ ライド等の第四級アンモニウム塩は, 広範囲の抗菌スペ クトルを有し，低濃度でも比較的強い殺菌力を示すこと から, 医療器具 ·環境等の消毒 · 殺菌に広く用いられて いる．しかし，正電荷を有する第四級アンモニウム塩 は，水溶液中で負電荷を有するレーヨン等のセルロース 系の素材に吸着することが指摘されている4 7).このこ とから, クロス含浸後定量的懸濁法に打ける市販品 B と市販品 C の結果は, クロス含浸後の絞り液中の第四 級アンモニウム塩濃度の低下が原因であると推察され る.さらに，第四級アンモニウム塩とアルカリ剂を配合 した環境清拭用クロスである市販品 B の液性がアルカ リ性 ( $\mathrm{pH}$ 約 11 : メーカー公表)であるにもかかわらず, 絞り液の液性を測定した結果, 中性付近 $(\mathrm{pH}$ 約 7) であ ったことから，アルカリ剤もクロスに吸着した可能性が 考えられた. また, ウイルス不活化効果については, 消 毒用エタノールクロスの絞り液と比較して市販品 $\mathrm{A} の$ 絞り液の方が高いウイルス不活化効果を示した. 同じ素 材のクロスに拉いて，エタノール溶液中の第四級アンモ ニウム塩の素材への吸着率は, 水溶液中の場合よりも低 く, 特に, クロスの素材にレーヨンを含む場合に, その 傾向が顕著であるとの報告もあることから, 市販品 $\mathrm{A}$ は, 薬液中の成分のクロスへの吸着率が低く, 薬剤の成 分が薬液中に残されていたことによって, 十分な効果が 保持されたと推察される5). そのため, 環境清拭用クロ スの各種微生物に対する評価には, クロスに含浸させよ うとする薬液のみでなく, クロスへの吸着も考慮し，ク ロスからの絞り液を用いることが重要である.

環境清拭用クロスを直接用いた清拭法において, 市販 品A では, A. baumannii, P. aeruginosa, E. faecalis, S. aureus, Influenza A virus が試験担体から検出されなく なり, 高い殺菌効果抢よびウイルス不活化効果を示し た. なた, Feline calicivirusについても, 試験担体上か らウイルスがほぼ検出されなくなり, 高いウイルス不活 化効果を示した. 一方, 市販品 $\mathrm{B}$ 抢よび市販品 $\mathrm{C}$ で は, 試験した全ての菌およびウイルスが試験担体から多 く検出された．さらに，市販品 B および市販品 $\mathrm{C}$ は, A. baumannii, E. faecalis, S. aureus および Influenza A virus の 4 種に対して, クロス含浸後定量的懸濁法では 短時間で高い殺菌効果抢よびウイルス不活化効果を示し たにもかかわらず, 清拭法では, 試験担体上に多くの細 菌およびウイルスが検出され，結果に相違が見られた。 また，市販品 A と同じクロスを用いた消毒用エタノー
ルについては, A. baumannii, P. aeruginosa, Influenza A virusに対する拭取り殺菌効果およびウイルス不活化効 果に相違がみられた。 クロスの素材や薬液成分, 配合量 の違いによって, 殺菌抢よびウイルス不活化に有効とさ れる成分のクロスへの吸着率に差があるとする前述の報 告に加えて, 清拭法では, クロス含浸後定量的懸濁法と 比較して, 処理表面で作用する薬液量は非常に少なく, 薬液の効果を発揮することは困難なことから, 生菌抢よ びウイルスが残存したと考えられる $3^{5,6,14)}$. そのため, 環境清拭用クロスの各種微生物に対する評価には，絞り 液によるクロス含浸後定量的懸濁法に加えて，薬液によ る化学的作用と物理的な除去力を同時に評価する清拭法 も評価法として利用しなければ，現実的な環境整備にお ける殺菌効果抢よびウイルス不活化効果と乘離する可能 性があり注意が必要である.

環境清拭用クロスからの絞り液に十分な効果が得られ なければ，処理表面で十分な効果が得られないばかりで なく, クロスに回収された微生物が再度拡散してしまう 恐れがあり，環境表面の清掃および消毒に使用する製品 は，実際の環境整備に基づいた適切な評価(絞り液を用 いたクロス含浸後定量的懸濁法および清拭法)を行うこ とが重要である15).

謝 辞 : 本論文の作成にあたりご協力頂きましたサラヤ株式会 社 松原 未来氏に御礼申し上げます.

利益相反自己申告 : 著者 中村絵美, 高見貴之, 加藤頼子, 吉 田葉子および谷口＼cjkstart暢はサラヤ株式会社の社員である.

\section{文献}

1）森山和郎, 登坂直規, 三村敬司, 都倉昭彦, 砂川富 正, 中島一敏, 他：山形県 A 病院に抢ける Van B 型 バンコマイシン耐性腸球菌集団分離事例，環境感染誌 2006; 21(3): 168-74.

2) Weber DJ, Rutala WA, Miller MB, Huslage K, Sickbert-Bennett E: Role of hospital surfaces in the transmission of emerging health care-associated pathogens: Norovirus, Clostridium difficile, and Acinetobacter species. Am J Infect Control 2010; 38 (5 Suppl 1): S25-33.

3) Hacek DM, Ogle AM, Fisher A, Robicsek A, Peterson LR: Significant impact of terminal room cleaning with bleach on reducing nosocomial Clostridium difficile. Am J Infect Control 2010; 38(5): 350-3.

4）影向範昭：塩化ベンザルコニウムの綿製品への吸着. 歯薬物療 $1986 ; 5(2): 105-8$.

5）中田精三, 伏見了, 梅下浩司, 上山博史, 高階雅 紀, 野口悟司, 他 : 消毒薬の医療材料への吸着につい て. 日手術医会誌 $2004 ; 25(2): 147-9$.

6）有馬美緒子, 中田精三，梅下浩司，高階雅紀，水谷綾 子, 花村 亮, 他：消毒剂の医療材料への吸着につい て2. 医療機器学 2006; 76(4): 101.

7) 大久保憲 : 総説 医療器材の洗浄・滅菌と環境整備の要 点. 日臨微生物誌 $2014 ; 24(1): 1-8$. 
8）高麗寛紀監修：ウエットワイパー類の除菌性能試験方 法. 一般社団法人日本衛生材料工業連合会作成, 2013 年 4 月 1 日制定.

9) ASTM International : Standard Guide for Assessment of Antimicrobial Activity Using a Time-Kill Procedure. [Designation: E 2315-03] 2008.

10) Blümel J, Glebe D: Leitlinie der Deutschen Vereinigung zur Bekämpfung der Viruskrankheiten (DVV) e.V. und des Robert Koch-Instituts (RKI) zur Prüfung von chemischen Desinfektionsmitteln auf Wirksamkeit gegen Viren in der Humanmedizin Fassung vom 1. August 2008. Bundesgesundheitsblatt Gesundheitsforschung Gesundheitsschutz 2008; 51: 937-45. [Article in Garman]

11) Mielke M, Pauli G, Schreier E, Schwebke I, Niedrig M, Exner M, et al.: Testing and product claims on the efficacy of antiviral disinfectants.Bundesgesundheitsblatt Gesundheitsforschung Gesundheitsschutz 2004;
47: $62-66$.

12）飯泉新吾：ウイルス実験学 総論. 国立予防衛生研究 所学友会編, 丸善, 東京, 1978, p. 479-81.

13）五味満裕, 矢野博子, 熊谷善敏, 大村 勲, 坂東健 司, 藤田直哉：ウエットワイパー類の除菌性能試験法 の開発. 日防菌防徽会誌 2014; 42(9): 469-74.

14）花村 亮：医療材料に対する消毒薬使用の注意点. INFECT CONTROL 2005; 14(4): 52-3.

15) Boyce JM, Opal SM, Chow JW, Zervos MJ, PotterBynoe G, Sherman CB, et al.: Outbreak of multidrugresistant Enterococcus faecium with transferable van B class vancomycin resistance. J Clin Microbiol 1994; 32 : 1148-53.

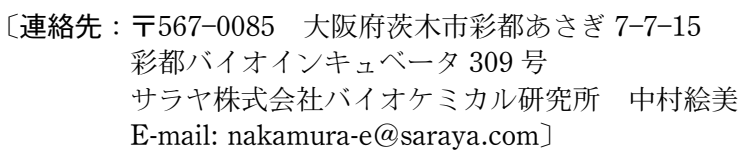

\title{
Evaluation of Sanitizing and Inactivation Efficacy of Wet Wipes against Bacteria and Viruses
}

\author{
Emi Nakamura ${ }^{1,3)}$, Takashi TAKAmi ${ }^{1)}$, Yoriko KATo $^{1)}$, Yoko YoshidA ${ }^{2,3)}$ and Toru TAniguchi ${ }^{1)}$ \\ 1) Biochemical Laboratory, ${ }^{2)}$ Academic Division, Saraya Co., Ltd., \\ 3) Faculty of Healthcare, Tokyo Healthcare University Postgraduate School
}

\begin{abstract}
Cleaning of environmental surfaces, as well as hand hygiene, is very important to prevent infection caused by microbes found in the environment of medical facilities, and disinfection is also required for environmental infection control in some cases. Recently, wet wipes made of nonwoven fabric impregnated with cleaner or disinfectant (medicinal solution) have been widely used for maintenance of the hospital environment. Evaluation of the sanitizing efficacy of wet wipes has mainly been based on allowing only the medicinal solution to contact with the test microbe, although the effectiveness of the product might be affected by adsorption of the medicinal solution into the fabric. This study evaluated the antibacterial and virus inactivation efficacy of three commercial products (brand $\mathrm{A}$, brand $\mathrm{B}$, and brand $\mathrm{C}$ ) and wet wipes impregnated with Ethanol for Disinfection (ethanol wipes) using (1) a quantitative suspension test in which the solution squeezed from each test product was allowed to contact with the test microbe, and (2) a fabric wipe-processing test in which the contaminated surface was wiped off with each test product. Brand A demonstrated superior effect against the test microbes in both the quantitative suspension test and fabric wipe-processing test in comparison with brand $\mathrm{B}$ and brand $\mathrm{C}$. Brand $\mathrm{A}$ was also superior to ethanol wipes for virus inactivation in the fabric wipe-processing test. Brand $\mathrm{B}$, brand $\mathrm{C}$, and ethanol wipes showed apparent differences between the results of the quantitative suspension test and fabric wipe-processing test. These results suggest that the combination of both tests is useful for rigorous evaluation of the effectiveness of wet wipes.
\end{abstract}

Key words : environmental measures, wet wipes, squeezed solution, quantitative suspension test, fabric wipe-processing test 